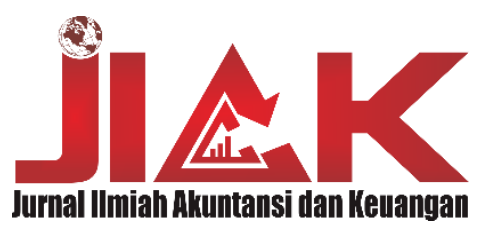

http://journal.stieputrabangsa.ac.id/index.php/jiak

ISSN: 2580-510X/ P-ISSN: 2548-9453

ARTICLE INFORMATION

Received May $5^{\text {th }} 2020$

Accepted January $30^{\text {th }} 2021$

Published January $31^{\text {st }} 2021$

DOI:

https://doi.org/10.32639/jiak. v9i2.571

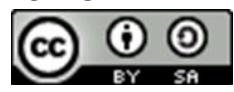

\section{Peran Pendamping Desa Dalam Pengelolaan Keuangan Desa}

\author{
Alva Fyniel ${ }^{1}$, Aprina Nugrahesthy Sulistya Hapsari ${ }^{2}$ \\ ${ }^{1,2)}$ Universitas Kristen Satya Wacana \\ email: alvafyniel@gmail.com ${ }^{1}$
}

\begin{abstract}
ABSTRAK
Tujuan dari penelitian ini adalah untuk mendeskripsikan dan menganalisis peran pendamping desa dalam pengelolaan dana desa di Desa Sepakung dari tahapan perencanaan, pelaksanaan, penatausahaan, pelaporan dan pertanggungjawaban. Metoda penelitian yang digunakan yaitu deskriptif kualitatif dengan menggunakan data primer dan sekunder yang sumber datanya diperoleh dari wawancara dan dokumentasi. Teknik analisis data yang dilakukan, yaitu: reduksi, penyajian data, dan penarikan kesimpulan. Untuk memastikan keabsahan dari data yang diperoleh dari narasumber, maka akan digunakan teknik triangulasi. Hasil penelitian menunjukkan bahwa pendamping desa di Desa Sepakung telah melaksanakan tugasnya sesuai dengan peraturan pemerintah tetapi kurang optimal. Ada beberapa kendala yang dialami, yakni: kurangnya tenaga teknik infrastruktur di lapangan, latar belakang pendidikan yang tidak sesuai, kurangnya pelatihan terhadap pendamping desa, jarak tempat tinggal yang jauh dengan desa binaan, dan minimnya honor yang diterima pendamping desa.
\end{abstract}

Kata kunci: Pendampingan Desa; Pengelolaan Keuangan Desa

\begin{abstract}
This study aims to describe and analyze the roles of village facilitators in managing village funds in Sepakung Village from planning, implementation, management, reporting, and accounting responsibility. This study applied descriptive qualitative using primary and secondary data gained from interview and documentation. The collected data were analyzed using some steps covering data reduction, presentation, and drawing conclusion. The study used triangulation to ensure the validity of the data. The result of the study showed that the facilitators of Sepakung Village has played their roles in accordance with the guidance from the government but less optimum in performing their roles. The challenges covered limited number of technical workers, unsuitable educational background, far distance from the facilitator's house to the guided village, and minimum incentive received by the facilitator.
\end{abstract}

Keywords: Village Facilitator; Village Fund Management 


\section{PENDAHULUAN}

Salah satu dari sembilan prioritas program pembangunan untuk Indonesia yang diungkapkan oleh Presiden Joko Widodo dalam Nawacita adalah pembangunan Indonesia yang dimulai dari pinggiran dengan memperkuat daerah-daerah dan desa dalam kerangka Negara Kesatuan Republik Indonesia. Sebagai perwujudan membangun desa serta memperjelas fungsi dan kewenangan desa, maka pemerintah mengeluarkan Undang-Undang Republik Indonesia Nomor 6 Tahun 2014 Tentang Desa. Salah satu upaya pemerintah dalam membangun daerah-daerah dan desa adalah dengan memberikan dana desa yang merupakan dana dari anggaran pendapatan dan belanja negara yang diperuntukkan bagi desa untuk pelaksanaan pembangunan dan pemberdayaan masyarakat desa. Proses penyaluran dana desa ini ditransfer secara bertahap.

Dalam penggunaan dana desa yang merupakan bagian dari keuangan desa juga perlu dilakukan evaluasi untuk memastikan bahwa setiap tahapan pengelolaan keuangan desa tersalurkan dengan baik dan tidak ada penyimpangan yang terjadi. Adanya keuangan desa yang diperuntukkan bagi pembangunan dan pemberdayaan masyarakat desa, diharapkan dapat meningkatkan status desa karena keuangan desa dapat membantu masyarakat desa dalam memanfaatkan potensi-potensi yang ada di desa, sehingga desa-desa yang ada dapat berkembang dan mandiri. Tujuan pembangunan kawasan perdesaan juga untuk mewujudkan masyarakat yang mandiri serta menciptakan desa yang mandiri dan berkelanjutan (Kemendesa.go.id, 2015).

Dana desa ini pertama kali dikucurkan pada tahun 2015 sebesar Rp20,76 triliun (Simorangkir, 2017). Dana tersebut mengalami peningkatan tiap tahunnya sampai dengan tahun 2019 yang ditunjukkan melalui Gambar 1.

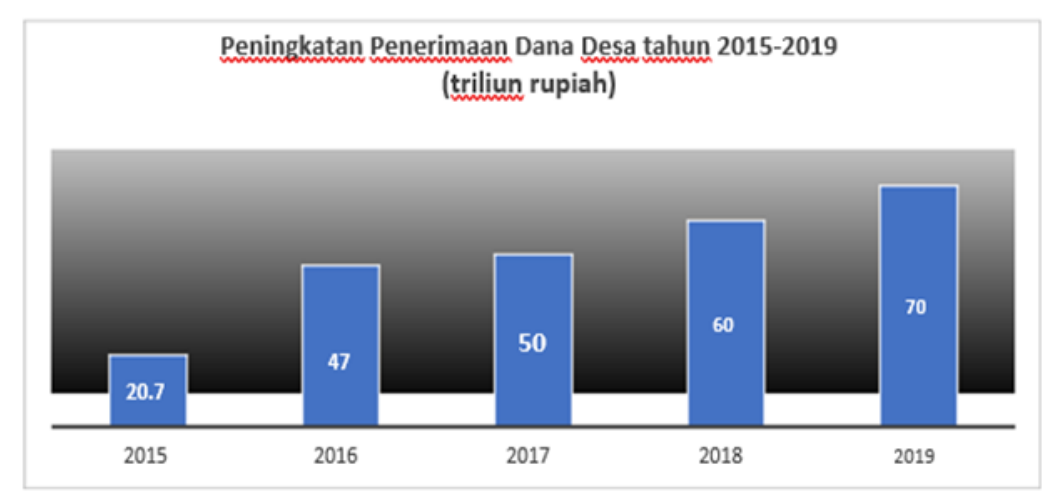

Sumber: Kementerian Keuangan Republik Indonesia (2019)

\section{Gambar 1. Peningkatan Penerimaan Dana Desa tahun 2015-2019}

Selama pengucuran dana desa ini, banyak hal telah dirasakan masyarakat di desa baik secara positif maupun negatif. Banyak desa yang mulai berkembang setelah adanya dana desa ini. Namun, penerimaan dana desa yang setiap tahunnya mengalami peningkatan, belum diimbangi dengan pengelolaan keuangan desa yang baik. Hal tersebut terjadi karena pihak desa dinilai kurang sigap dalam mempersiapkan anggaran pendapatan dan belanja desa, para kepala desa masih kesulitan untuk mengelola dan mempertanggungjawabkan laporan keuangan penggunaan dana desa sehingga penerapannya pun tidak sempurna (Lestari, 2019). Masalah lainnya yang dialami dalam suatu desa terkait pengelolaan keuangan desa adalah korupsi dana desa. Menurut survei yang dilakukan oleh Indonesia Corruption Watch (ICW) ada sebanyak 181 kasus korupsi dalam pengelolaan keuangan desa, diantaranya: 17 kasus pada 2015, 41 kasus di tahun 2016, 96 kasus pada tahun 2017 dan hingga Juni 2018 ada sebanyak 27 kasus (Kompas.com, 2018). Saat ini, potensi fraud tentang pengelolaan dana desa 
cukup mengkhawatirkan di Indonesia, mulai dari proses perencanaan, implementasi dan pelaporan yang ada dalam regulasi dan kelembagaan, tata laksana, pengawasan dan sumber daya manusia (Seputro, Wahyuningsih, \& Sunrowiyati, 2017).

Jaksa Agung mengatakan bahwa ada enam permasalahan besar yang ditemukan kejaksaan agung dalam pengelolaan keuangan desa, diantaranya adalah: pertama, berkaitan dengan pemotongan saat pencairan. Jadi, ada sejumlah daerah yang menerima dana desa tidak sesuai alokasi yang harusnya mereka terima. Kedua, adanya proyek fiktif yang didanai dengan dana desa. Ketiga adalah penggelembungan proyek. Keempat, berkaitan dengan rendahnya kemampuan manajerial dari aparatur desa. Kelima, berkaitan dengan penggunaan rekening pribadi sebagai tempat penggelembungan dana. Keenam, penyaluran dana yang harus dilakukan dari rekening umum kas negara ke rekening umum kas daerah baru ke rekening desa (Kontan.co.id, 2017). Masalah-masalah seperti ini tidak semata-mata karena moral yang tidak baik, tetapi juga ada faktor lain yang menyebabkan hal tersebut bisa terjadi, seperti kurangnya pengetahuan aparatur desa tentang pencatatan dan pembukuan akuntansi yang baik karena di satu sisi, tak bisa dipungkiri bahwa masih banyak perangkat desa yang rata-rata pendidikan terakhir adalah SMA (Manafe, 2015). Kendala lain yang ditemui dalam pengelolaan dana desa yakni pemahaman regulasi, kurangnya fungsi pembinaan dari pemda/kecamatan, kekhawatiran/ketakutan melakukan kesalahan dari aparat desa, pergantian aparat desa seiring pilkades serentak, serta kurangnya disiplin dalam pelaporan (Bpkp.go.id, 2019).

Dalam rangka membantu aparat desa dalam mengelola keuangan desa, sangat diperlukan adanya peran pendamping desa. Pendamping desa inilah yang menjadi perpanjangan tangan dari pemerintah dalam memastikan terselenggaranya pengelolaan keuangan desa dengan baik dan tanpa ada pelanggaran (Tribunnews.com, 2015). Salah satu tugas dari pendamping desa adalah mendampingi desa dalam pengelolaan keuangan desa yang didalamnya terdapat perencanaan, pelaksanaan, penatausahaan, pelaporan dan pertanggungjawaban terhadap pembangunan desa dan pemberdayaan masyarakat desa. Namun, hingga pendamping desa telah dibentuk, masalah-masalah yang ada di desa belum sepenuhnya bisa teratasi, baik itu pembangunan maupun pemberdayaan masyarakat. Pendamping desa dianggap kurang memiliki kontribusi terhadap desa. Mereka dianggap hanya seperti tenaga survei atau pengumpul data, sehingga perannya dalam membangun desa masih kurang (Movanita, 2017). Selain itu, hingga kini jumlah pendamping desa tidak sesuai dengan jumlah desa yang ada di Indonesia, akibatnya peran pendamping desa dinilai kurang maksimal terhadap pengelolaan dana desa. Idealnya, seorang pendamping desa hanya dapat melakukan pendampingan terhadap dua sampai empat desa saja (Kompas.com, 2015). Pendamping desa adalah salah satu kekuatan yang dapat membantu mempercepat langkah menjadi desa yang mandiri. Seorang pendamping desa harus memiliki beberapa kemampuan sekaligus yakni kemampuan berbaur dalam karakter kehidupan warga dampingan sekaligus melakukan pemberdayaan (Berdesa.com, 2018). Maka dari itu, pendamping desa dituntut untuk memiliki kompetensi agar setiap tugas, fungsi, dan tanggung jawab mampu dilaksanakan dalam hal memberikan pelayanan, sehingga peran pendamping desa akan semakin nyata.

Penelitian terdahulu tentang peran pendamping desa dilakukan oleh Triyanto (2018) yang mengungkapkan bahwa pendamping desa telah melakukan tugas, pokok dan fungsinya sebagai pendamping desa dengan penuh tanggungjawab. Selain itu, penelitian yang dilakukan oleh Susanti (2017) mengungkapkan bahwa peran pendamping desa dirasakan sangat membantu bagi perangkat desa dari sisi pemberdayaan masyarakat dalam partisipatif melalui musyawarah desa. Hasil yang berbeda ditemukan oleh Lobor, Ogotan dan Londa (2018) yang menyatakan bahwa pada umumnya, peran pendamping desa dalam pengelolaan dana desa, dilihat dari beberapa hal, yaitu: perencanaan pendamping desa masih belum memperhatikan prioritas penggunaan dana desa, kemudian pendamping desa belum memiliki kemampuan yang memadai dalam hal pelaksanaan, serta pemantauan masih kurang optimal karena jarak tempat pendamping desa dengan desa yang didampingi cukup jauh serta jalan yang kurang memadai. Sementara itu, pendamping desa belum memaksimalkan perannya dalam proses pembuatan program pemberdayaan, pelaksanaan dan evaluasi karena pendamping desa masih 
bekerja secara parsial, belum dapat bekerjasama dan melakukan koordinasi dalam satu tim kerja (Suswanto \& Sulistyoningsing, 2018). Penelitian sebelumnya juga dilakukan oleh Widiyarta (2017) yang menyatakan bahwa aparat desa dan masyarakat masih mengeluhkan kinerja dari pendamping desa karena tidak sesuai dengan peran yang harus dilakukan. Selain itu, kinerja pendamping desa tidak dievaluasi sesuai aturan yang ada, tidak melibatkan pemerintah lokal, dan instrumen yang digunakan kurang dapat untuk mengukur kinerja serta pendamping desa belum secara maksimal menjalankan program pemberdayaan desa sesuai Peraturan Menteri Desa, Pembangunan Daerah Tertinggal dan Transmigrasi Nomor 3 Tahun 2015, baik dalam perencanaan, pelaksanaan, maupun pemantauan terhadap pembangunan desa serta koordinasi yang dilakukan terhadap pemerintah desa (Alpisyahrin,2019). Bahkan, masih banyak juga masyarakat yang belum memahami tentang keberadaan pendamping desa untuk mendampingi pelaksanaan program, pendampingan pada pengawasan pembangunan dan komunikasi pendamping desa sehingga dinilai kurang baik sehingga ada masyarakat yang tidak menyetujui adanya program pendamping desa (Susanti, 2015).

Tujuan penelitian ini adalah untuk mendeskripsikan dan menganalisis peran pendamping desa dalam pengelolaan dana desa di Desa Sepakung dari tahapan perencanaan, pelaksanaan, penatausahaan, pelaporan dan pertanggungjawaban. Alasan pemilihan Desa Sepakung adalah karena dari hasil wawancara awal dengan narasumber diperoleh informasi bahwa pendamping desa di desa tersebut hanya ada satu orang yang mendampingi tiga desa sehingga peran pendamping desa dirasa belum menonjol. Selain itu pendamping desa tersebut tinggal jauh dari Desa Sepakung. Adanya jarak itu menjadi kendala dalam pelaksanaan perannya sejauh ini. Berdasarkan latar belakang tersebut, maka rumusan masalah dalam penelitian ini adalah bagaimana peran pendamping desa dalam pengelolaan keuangan desa di Desa Sepakung?

Penelitian ini diharapkan dapat bermanfaat bagi pendamping desa, yaitu sebagai bahan evaluasi terkait dengan perannya dalam pengelolaan keuangan desa. Manfaat lain dari penelitian ini juga bagi pemerintah desa, yaitu sebagai bahan evaluasi dalam hal kerjasama dengan pendamping desa untuk mewujudkan keuangan desa yang terkelola dengan baik mulai dari perencanaan hingga pertanggungjawaban. Penelitian ini juga diharapkan menjadi rekomendasi dan evaluasi bagi pemerintah pusat dalam hal pengelolaan program pendamping desa dan keuangan desa agar kedepannya masalahmasalah yang ada di desa selama ini dapat diminimalisir. Terakhir, penelitian ini diharapkan dapat membawa manfaat bagi tambahan literatur akuntansi desa.

\section{KAJIAN LITERATUR}

\section{Pengelolaan Keuangan Desa}

Desa merupakan suatu kesatuan masyarakat hukum terkecil yang ada di pemerintahan dan diakui dalam sistem pemerintahan NKRI. Sebagai upaya dalam memperjelas fungsi dan kewenangan desa, serta kedudukan desa dan masyarakat desa maka pemerintah menerbitkan Undang-Undang Republik Indonesia nomor 6 tahun 2014 Tentang Desa. Dalam rangka untuk mendukung pelaksanaan fungsi dan tugas desa, maka pemerintah mengalokasikan dana untuk keperluan di tiap-tiap desa. Adapun sumbersumber pendapatan desa adalah pendapatan asli daerah, dana desa, alokasi dana desa dari kabupaten/kota, bantuan keuangan dari APBD provinsi dan APBD kabupaten/kota, hibah dan sumbangan pihak ketiga, serta lain-lain pendapatan desa yang sah. Salah satu pendapatan desa adalah dana desa yang bersumber dari APBN. Dana desa akan ditransfer ke masing-masing desa dan akan di kelola oleh aparat desa, seperti: kepala desa, sekretaris desa, kepala urusan dan kepala seksi, dan kepala urusan keuangan berdasarkan asas transparansi, akuntabel, partisipatif yang dilakukan dengan tertib dan disiplin anggaran (Peraturan Menteri Dalam Negeri Nomor 20 Tahun 2018). 
Berdasarkan Peraturan Menteri Dalam Negeri nomor 20 Tahun 2018 tentang pengelolaan keuangan desa, proses pengelolaan keuangan desa dilakukan dengan beberapa tahap. Tahap pertama dalam pengelolaan keuangan desa adalah perencanaan keuangan desa yang berhubungan dengan penerimaan dan pengeluaran pemerintah desa pada tahun anggaran yang dianggarkan dalam APB desa. Proses perencanaan keuangan desa adalah dengan menyusun rancangan anggaran pendapatan dan belanja desa. Sekretaris akan mengkoordinasikan penyusunan rencana anggaran pendapatan dan belanja desa berdasarkan rencana kerja pemerintah desa tahun berkenaan yang diatur dalam peraturan bupati/wali kota setiap tahun. Rancangan APB desa inilah yang akan dijadikan sebagai bahan dalam menyusun peraturan desa tentang APB Desa. Selanjutnya, sekretaris desa akan menyampaikan rancangan peraturan desa tersebut kepada kepala desa yang akan disampaikan dalam musyawarah badan permusyawaratan desa untuk dibahas dan disepakati bersama yang nantinya akan disampaikan kepada bupati/wali kota melalui camat yang akan dilengkapi dengan dokumen pendukung.

Setelah rancangan peraturan desa tentang APB Desa diserahkan kepada bupati/wali kota, selanjutnya akan dilakukan pemanggilan kepada kepala desa atau aparat desa terkait untuk pelaksanaan evaluasi yang dituangkan dalam keputusan bupati/wali kota yang akan ditetapkan sebagai peraturan desa. Bupati/wali kota dapat memberikan wewenang untuk mengevaluasi peraturan desa tentang APB desa kepada camat dan selanjutnya rancangan tersebut akan ditetapkan oleh kepala desa menjadi peraturan desa. Pemerintah desa dapat melakukan perubahan terhadap peraturan desa tentang APB desa yang telah ditetapkan apabila ada penambahan atau pengurangan pendapatan desa tahun berjalan, keadaan yang mengharuskan dilakukannya pergeseran objek belanja dan kegiatan yang belum dilaksanakan tahun sebelumnya akan dilaksanakan pada tahun anggaran berjalan. Terkait perubahan ini, kepala desa memberitahukan tentang perubahan tersebut kepada badan permusyawaratan desa yang kemudian disampaikan kepada bupati/wali kota.

Tahap Kedua dalam pengelolaan keuangan desa adalah pelaksanaan. Pelaksanaan pengelolaan keuangan desa merupakan proses yang dilakukan oleh pemerintah desa untuk memanfaatkan keuangan desa yang di transfer oleh pemerintah pusat untuk merealisasikan program-program yang ada di desa. Penerimaan dan pengeluaran dana desa dilaksanakan melalui rekening kas desa pada bank yang ditunjuk oleh bupati/wali kota dan dibuat oleh pemerintah desa dengan tanda tangan kepala desa dan kaur keuangan. Nomor rekening yang telah dibuat akan dilaporkan kepada bupati/wali kota yang selanjutnya akan dilaporkan kepada gubernur dengan tembusan kepada menteri guna untuk pengendalian penyaluran dana transfer. Kepala desa akan memberikan tugas kepada kaur dan kasi pelaksana kegiatan anggaran untuk menyusun dokumen pelaksanaan anggaran, yaitu: rencana kegiatan dan anggaran desa, rencana kerja kegiatan desa dan rencana anggaran biaya yang selanjutnya akan diserahkan kepada kepala desa melalui sekretaris desa untuk dilakukan verifikasi sebelum disetujui kepala desa. Jika ada perubahan peraturan desa tentang APB desa maka akan disusun dokumen perubahan pelaksanaan anggaran akan dibuat oleh kepala urusan dan kepala seksi pelaksana kegiatan yang selanjutnya akan diserahkan kepada sekretaris desa untuk diverifikasi dan diberikan kepada kepala desa untuk disetujui. Sementara itu, kepala urusan keuangan akan menyusun rencana arus kas desa berdasarkan dokumen pelaksanaan anggaran yang telah disetujui kepala desa.

Setelah RAK desa selesai dibuat maka akan diserahkan kepada sekretaris desa untuk diverifikasi sebelum disetujui oleh kepala desa. Pelaksanaan kegiatan dilakukan dengan pengadaan melalui swakelola yang dilaksanakan dalam tahun anggaran berkenaan. Dalam pelaksanaan kegiatan anggaran tersebut juga diajukan surat permintaan pembayaran dengan menyertakan laporan perkembangan pelaksanaan kegiatan dan anggaran. Kepala urusan keuangan akan mencatat transaksi pengeluaran anggaran dan akan diperiksa kesesuaian bukti transaksi dengan pertanggungjawaban pencairan anggaran. Laporan 
akhir realisasi pelaksanaan kegiatan dan anggaran akan disampaikan oleh kaur dan kasi pelaksana setelah seluruh kegiatan selesai.

Tahap ketiga adalah penatausahaan. Dalam proses penatausahaan, kepala desa sebagai penanggungjawab penatausahaan keuangan akan dibantu oleh bendahara desa, harus menyiapkan buku pembantu kas umum, yang terdiri dari: buku pembantu bank, buku pembantu pajak dan buku pembantu panjar. Buku kas umum ini akan ditutup setiap akhir bulan untuk dilaporkan oleh bendahara kepada sekretaris desa untuk dilakukan verifikasi, evaluasi dan analisis terhadap laporan keuangan yang selanjutnya akan dilaporkan untuk disetujui oleh kepala desa. Tahapan keempat adalah pelaporan pengelolaan keuangan desa. Proses pelaporan keuangan desa menurut Peraturan Menteri Dalam Negeri Nomor 20 Tahun 2018 tentang pengelolaan keuangan desa menjelaskan bahwa kepala desa akan menyampaikan laporan pelaksanaan APB desa semester pertama dan laporan realisasi kegiatan kepada bupati/wali kota melalui camat. Selanjutnya, laporan konsolidasi pelaksanaan APB desa akan dilaporkan kepada menteri. Tahap Kelima adalah Pertanggungjawaban pengelolaan keuangan desa. Dalam proses pertanggungjawaban pengelolaan keuangan desa, kepala desa pada setiap akhir tahun anggaran akan menyampaikan laporan pertanggungjawaban APB desa kepada bupati/wali kota melalui camat. Laporan pertanggungjawaban disertai laporan realisasi APB desa dan catatan atas laporan keuangan, laporan realisasi kegiatan, dan daftar program yang masuk ke desa. Pertanggungjawaban pengelolaan keuangan desa akan disampaikan kepada menteri dan diinformasikan kepada masyarakat melalui media informasi (Peraturan Menteri Dalam Negeri Nomor 20 Tahun 2018).

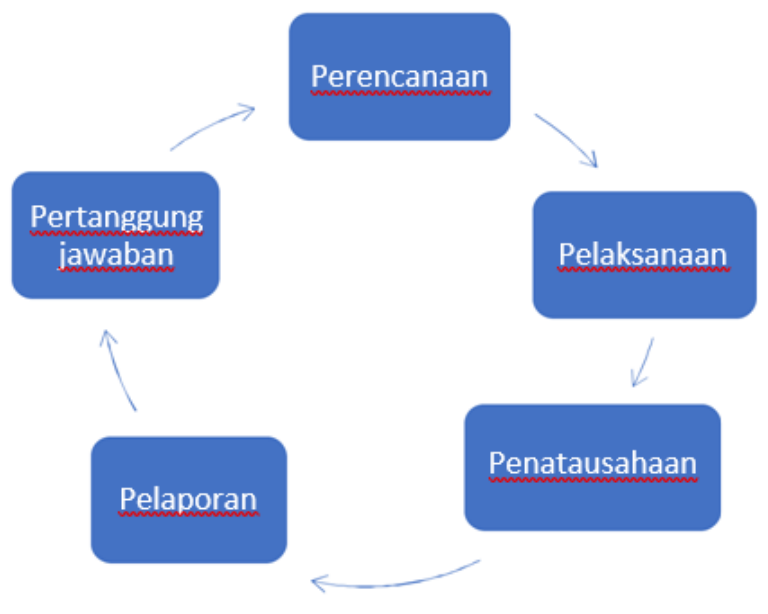

Gambar 2. Tahapan Pengelolaan Keuangan Desa

\section{Pendamping Desa}

Berdasarkan Peraturan Menteri Desa Pembangunan Daerah Tertinggal Dan Transmigrasi No.3 Tahun 2015 Tentang Pendamping Desa, pasal 1 ayat (14) menyatakan bahwa pendampingan desa adalah kegiatan untuk melakukan tindakan pemberdayaan masyarakat melalui asistensi, pengorganisasian, pengarahan dan fasilitasi Desa. Pendamping desa memiliki tugas dalam hal pendampingan terhadap desa untuk menyelenggarakan pembangunan desa dan pemberdayaan masyarakat. Tujuan dari pendampingan desa, yaitu: 1) Meningkatkan kapasitas, efektivitas dan akuntabilitas pemerintahan desa 
dan pembangunan desa; 2). Meningkatkan prakarsa, kesadaran dan partisipasi masyarakat desa dalam pembangunan desa yang partisipatif; 3) Meningkatkan sinergi program pembangunan desa antarsektor; 4) Mengoptimalkan aset lokal desa secara emansipatoris.

Dalam Peraturan Menteri Desa Pembangunan Daerah Tertinggal Dan Transmigrasi No.3 Tahun 2015 Tentang Pendamping Desa juga diungkapkan tugas pokok pendamping desa, yaitu: 1) Mendampingi desa dalam setiap tahap pengelolaan keuangan desa dalam pembangunan dan pemberdayaan masyarakat, 2) Mendampingi desa dalam pengelolaan pelayanan sosial, pemanfaatan sumber daya, pembangunan sarana dan prasarana dan pemberdayaan masyarakat desa, 3) Peningkatan kapasitas bagi aparat desa dalam hal pembangunan dan pemberdayaan masyarakat, 4) Melakukan pengorganisasian dalam kelompok-kelompok masyarakat desa, 5) Peningkatan kapasitas bagi kader pemberdayaan masyarakat desa, 6) Melakukan pendampingan terhadap desa dalam proses pembangunan secara partisipatif, 7) Melakukan koordinasi pendampingan dan memfasilitasi laporan pelaksanaan pendampingan. Pada akhir penugasan, Menteri akan melakukan evaluasi kinerja terhadap pendamping desa sesuai Peraturan Menteri Desa Pembangunan Daerah Tertinggal Dan Transmigrasi No.3 Tahun 2015 Tentang Pendamping Desa pasal 30. Evaluasi kinerja ini dilakukan oleh Menteri dan dilakukan secara berjenjang.

\section{METODE}

\section{Jenis Penelitian dan Teknik Pengumpulan Data}

Metoda penelitian yang digunakan yaitu deskriptif kualitatif. Metoda kualitatif digunakan sebagai prosedur penelitian yang menghasilkan data deskriptif mengenai peran pendamping desa dalam pengelolaan keuangan desa di Desa Sepakung, dilihat dari fenomena-fenomena yang terjadi saat ini, sesuai dengan peraturan Menteri Desa, Daerah Tertinggal dan Transmigrasi tentang Pendamping Desa. Metoda deskriptif kualitatif dipilih karena pada penelitian ini akan berfokus pada peran pendamping desa dalam pengelolaan keuangan desa pada tahap perencanaan, pelaksanaan, penatausahaan, pelaporan, dan pertanggungjawaban keuangan desa. Penelitian ini akan menggunakan data primer dan sekunder yang sumber datanya diperoleh dari wawancara dan dokumentasi. Kegiatan wawancara dilakukan secara mendalam terhadap narasumber, yaitu: kepala desa, sekretaris desa, bendahara desa dan pendamping desa dengan bantuan panduan pertanyaan yang dapat dikembangkan lebih lanjut pada saat melakukan wawancara. Selain itu, tahap pengumpulan data juga dilakukan dengan mendokumentasikan dokumen-dokumen terkait peran pendamping desa dalam pengelolaan keuangan desa yang dapat digunakan untuk memperkuat data yang ada.

\section{Teknik Analisis Data}

Teknik analisis data yang akan dilakukan dalam penelitian ini terdiri dari beberapa tahapan: pertama, reduksi data untuk merangkum, memilih hal-hal pokok, dan memfokuskan pada hal-hal yang penting yang berkaitan dengan fokus penelitian yaitu peran pendamping desa dalam pengelolaan keuangan desa. Kedua, penyajian data dilakukan dengan cara menguraikan dan menjelaskan keadaan yang ada, sesuai dengan hasil data yang diperoleh dari wawancara dan dokumentasi yang dilakukan kepada kepala desa, sekretaris desa, bendahara desa dan pendamping desa di Desa Sepakung. Ketiga, penarikan kesimpulan yang dilakukan dengan penarikan intisari berdasarkan hasil wawancara dengan narasumber dan dokumentasi terhadap dokumen-dokumen pendukung terkait dengan pengelolaan keuangan dan peran pendamping desa (Miles \& Huberman, 2014). Untuk memastikan keabsahan dari data yang diperoleh dari narasumber, maka akan digunakan teknik triangulasi. Teknik triangulasi ini akan melibatkan kepala desa, sekretaris desa, bendahara desa dan pendamping desa. Tujuan penggunaan teknik triangulasi adalah untuk memeriksa dan membandingkan serta menilai data yang diperoleh dari wawancara dengan beberapa pihak terkait dan juga dari hasil dokumentasi berupa dokumen-dokumen yang berkaitan dengan pendamping desa. 


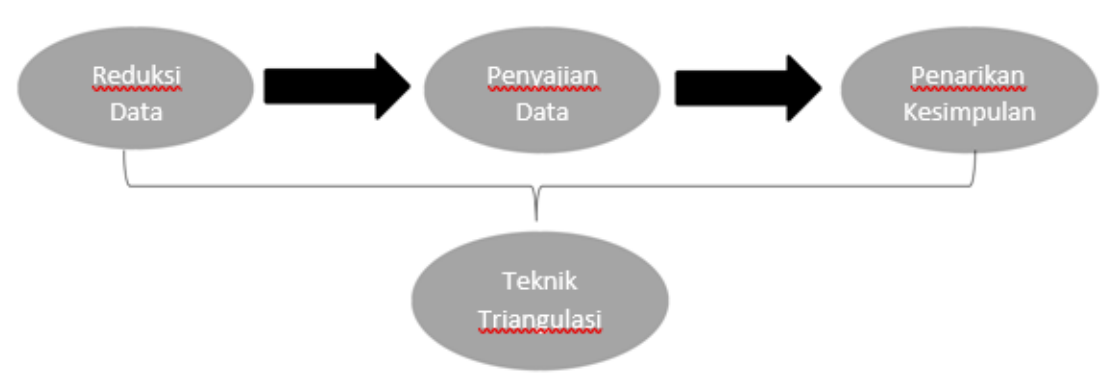

Gambar 3. Teknik Analisis Data

\section{HASIL DAN PEMBAHASAN}

\section{Gambaran Objek Penelitian}

Desa Sepakung merupakan salah satu dari sepuluh desa yang ada di Kecamatan Banyubiru, yang terletak di daerah pegunungan dengan ketinggian antara 900-1000 mdpl. Batas wilayah Desa Sepakung sebelah utara berbatasan dengan Kelurahan Tegaron, sebelah selatan berbatasan dengan Kelurahan Nogo Saren, sebelah timur berbatasan dengan Kelurahan Kebumen dan sebelah barat berbatasan dengan Kelurahan Wirogomi. Luas daerah Desa Sepakung kurang lebih 786,670 Hektar terdiri dari sawah: 165,120 ha, pekarangan: 87,200 ha, perkebunan: 275,150 ha, hutan: 192,100 ha dan lainnya: 67,100 ha.

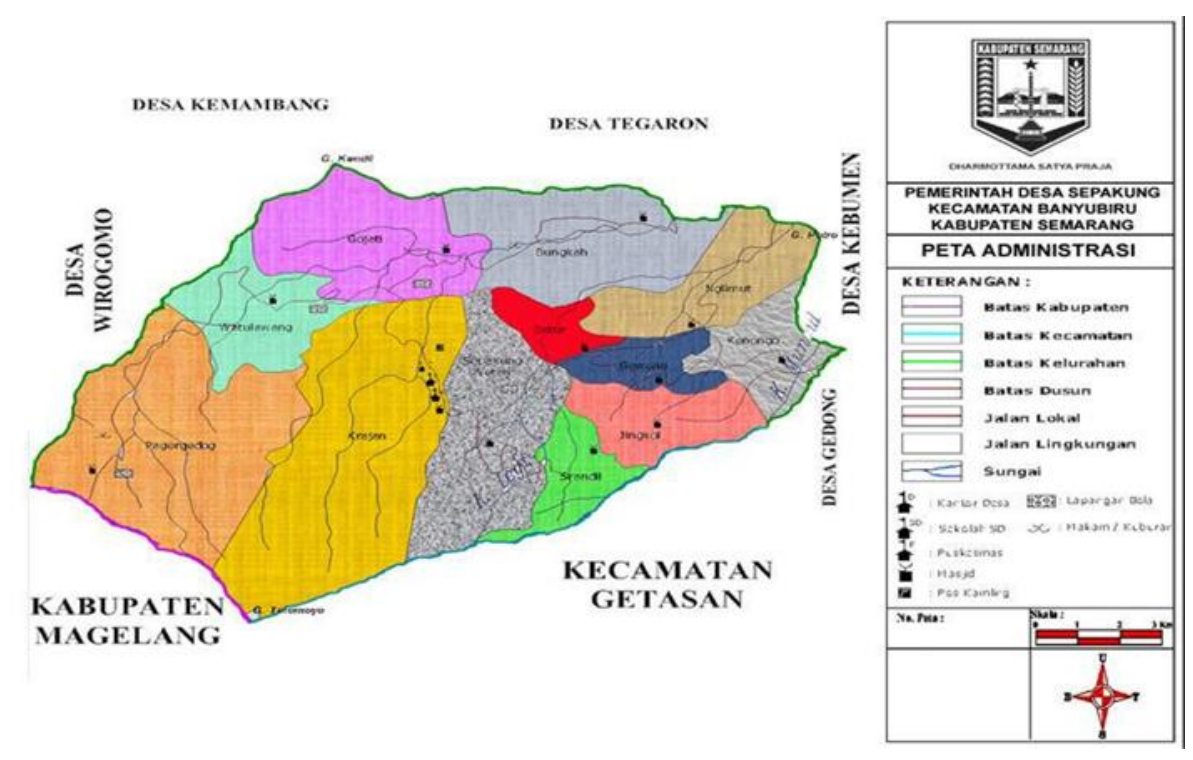

Sumber: Desa Sepakung.id (2017)

Gambar 4. Peta Desa Sepakung

Desa Sepakung memiliki sekitar 1,335 kepala keluarga dengan jumlah 4,829 jiwa, sekitar 2,443 jiwa lakilaki dan 2,386 jiwa perempuan. Penduduk Desa Sepakung tersebut tersebar di 12 dusun, 17 RW dan 40 
RT. Mata pencaharian penduduk di Desa Sepakung rata-rata berkebun dan bertani. Selain itu, di Desa Sepakung juga dikenal dengan potensi wisata yang menjadi daya tarik tersendiri di desa ini, seperti wisata Kali Kulon, wisata alam Cemoro Sewu, wisata Klarasan Hill, wisata alam Gumuk Reco dan air terjun Goa Semar.

Adapun visi dari Desa Sepakung adalah mewujudkan Desa Sepakung Menjadi Desa mandiri melalui bidang pertanian, industri kecil dan wisata desa. Visi tersebut didukung oleh misi, yaitu: 1). Memperbaiki dan menambah sarana dan prasarana yang dibutuhkan untuk meningkatkan SDM melalui pendidikan formal maupun informal, 2). Bekerja sama dengan petugas penyuluh lapangan untuk meningkatkan hasil pertanian, 3). Meningkatkan usaha Pertanian, 4). Meningkatkan dan mengelola Pendapatan Asli Desa, 5). Mewujudkan pemerintahan yang baik dan bersih melalui pelaksanaan otonomi daerah.

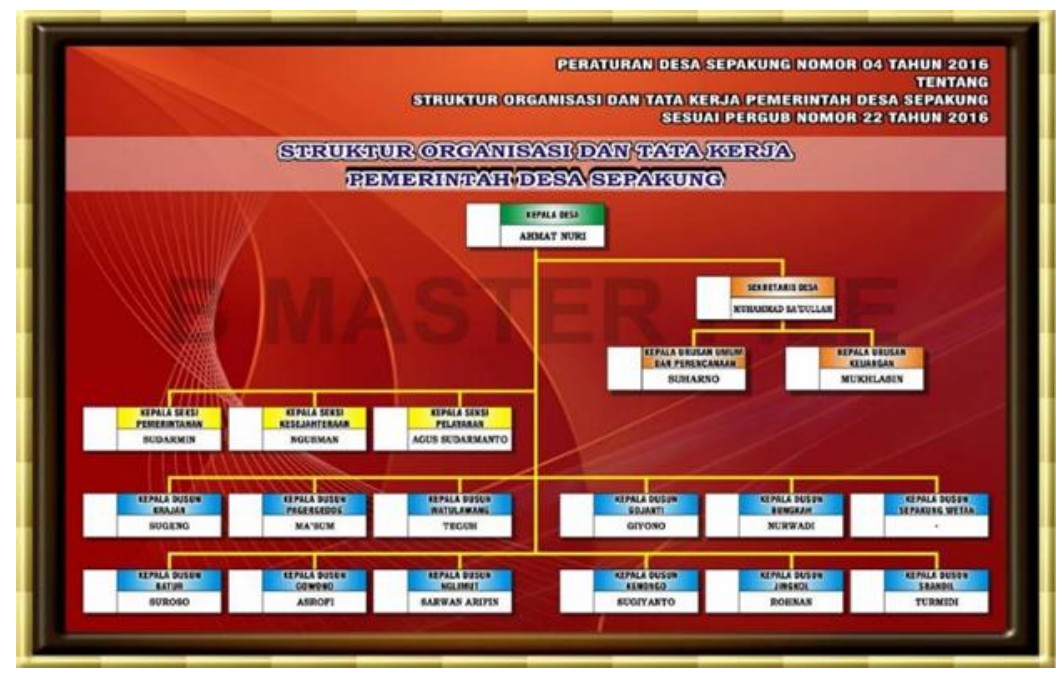

Sumber: Desa Sepakung.id (2019)

\section{Gambar 5. Struktur Organisasi Desa Sepakung}

Gambar 5 menunjukkan struktur organisasi pemerintahan Desa Sepakung. Sistem pemerintahan di Desa Sepakung dikepalai oleh Kepala Desa yang dijabat oleh Bapak Ahmat Nuri. Dalam menjalankan tugasnya, kepala desa dibantu oleh Sekretaris Desa, yaitu Bapak Muhammad Sa'dullah yang membawahi kepala urusan umum dan kepala urusan keuangan. Bagian lain dari struktur pemerintahan yang ada di Desa Sepakung, yaitu: Kepala seksi pemerintahan, kepala seksi kesejahteraan, kepala seksi pelayanan, dan kepala-kepala dusun yang langsung berkoordinasi kepada kepala desa.

Dalam setiap proses tahapan pengelolaan keuangan desa, khususnya dana desa, Desa Sepakung didampingi oleh satu orang pendamping desa. Pendamping desa ini yang akan mendampingi dan memantau setiap proses pengelolaan keuangan desa dari perencanaan hingga pertanggungjawaban, baik dalam pembangunan infrastruktur maupun pemberdayaan masyarakat desa.

\section{Peran Pendamping Desa di Tahapan Perencanaan}

Tahap perencanaan di Desa Sepakung, diawali dengan rapat di setiap dusun. Masyarakat akan menyampaikan usulan-usulan yang akan di sampaikan pada saat melakukan musyawarah desa. Penyusunan rencana kegiatan ini dilaksanakan pada saat menjelang awal tahun anggaran baru atau berakhirnya tahun anggaran berjalan. Penyusunan daftar usulan rencana kegiatan yang dilakukan pada saat musrenbangdes melibatkan seluruh komponen yang ada di desa untuk menyampaikan aspirasi 
mengenai usulan kegiatan yang menjadi kebutuhan masyarakat. Hal ini sesuai dengan apa yang diungkapkan oleh Kepala Desa (10 Maret 2020):

"Sebelum diadakan musrenbangdes, masyarakat di dusun akan melakukan rapat untuk membahas tentang usulan dari masyarakat yang akan disampaikan pada saat dilakukan musyawarah desa, tentunya usulan tersebut dituangkan dalam RPJMDes. Usulan tersebut akan disampaikan oleh perwakilan dusun kepada forum untuk kemudian dijadikan sebagai bahan pertimbangan pemerintah desa untuk menentukan kebijakan".

Selaras dengan hal yang disampaikan oleh kepala desa, sekretaris desa juga menyampaikan (22 Januari 2020):

"Pada saat Musrenbangdes, kan dipimpin oleh Kepala Desa dan dihadiri oleh perwakilan kecamatan dan perwakilan dusun serta elemen masyarakat lainnya, disitu disampaikan RPJMDes dan aspirasi dari masyarakat, kami tampung".

Pendamping desa juga terlibat dalam rapat dusun dan menampung usulan-usulan dari masyarakat. Pendamping desa memiliki kontribusi penting dalam mengarahkan penyusunan rencana kegiatan agar sesuai dengan prioritas dan kebutuhan masyarakat yang dituangkan dalam pembahasan RPJMDes, RKPDes dan APBDes yang dibahas dalam musyawarah desa yang anggarannya diambil melalui Anggaran Pendapatan Belanja Negara (APBN). Pendamping desa mengatakan (2 Maret 2020):

"saya akan turun langsung ke masyarakat untuk menggali informasi dan melihat apa yang terjadi di masyarakat dan bekerjasama dengan aparat desa untuk penyelesaiannya. Biasanya di desa ada semacam perkumpulan antara masyarakat desa dan aparat desa, disitulah akan dibicarakan apa yang akan direncanakan kedepannya".

Pendapat dari pendamping desa tersebut, kemudian dikonfirmasi oleh kepala desa yang mengatakan:

"Pendamping desa ikut terlibat juga dengan turun langsung ke dusun untuk mendampingi desa dan menampung aspirasi masyarakat. Pendamping desa juga ikut serta dalam rapat dusun"

Dalam tahap perencanaan ini, pendamping desa juga melakukan pemantauan pada saat penyusunan program. Pemantauan atau monitoring merupakan kegiatan yang sangat penting dalam proses pengembangan dan pemberdayaan masyarakat, karena dengan adanya pemantauan, maka akan diketahui sejauh mana efektifitas dan efisiensi untuk memastikan penyusunan program berjalan sesuai prioritas kebutuhan dari desa Sepakung. Bentuk pemantauan yang dilakukan oleh pendamping desa di Desa Sepakung adalah dengan ikut dalam pembuatan RABDes. Hal ini diungkapkan pendamping desa:

"Pemantauan yang dilakukan itu misalnya dalam pembuatan RABDes. Jadi kita ikut mengukur rabat atau drainase, kemudian disesuaikan dengan budget".

Pendamping desa melakukan tugasnya sesuai untuk mendampingi desa dalam proses penyusunan RPJMDes, RKPDes dan APBDes agar sesuai dengan peraturan pemerintah dan kebutuhan masyarakat.

Peran Pendamping Desa di Tahapan Pelaksanaan

Pada tahap pelaksanaan, usulan-usulan dari masyarakat dusun yang dituangkan dalam RPJMDes, RKPDes dan APBDes Desa Sepakung, Kecamatan Banyubiru akan mulai dikerjakan dengan menggunakan Anggaran Pendapatan Belanja Negara (APBN). Seluruh penerimaan dan pengeluaran desa dilaksanakan melalui Rekening Kas Desa. Hal tersebut seperti yang diungkapkan oleh Bendahara desa:

"semua pemasukan dan pengeluaran di desa harus melalui rekening desa. Desa hanya memiliki satu rekening."

Pencairan dana dalam rekening kas desa ditandatangani oleh kepala desa dan bendahara desa. Pada saat melakukan pencairan dana desa, desa harus melampirkan beberapa dokumen terkait, seperti yang disampaikan sekretaris desa: 
"Kalau desa mau mencairkan dana ke pemerintah, desa harus melampirkan APBDes, Laporan realisasi APBDes tahun sebelumnya, laporan pelaksanaan pembangunan desa, laporan kinerja pemerintah desa, rencana penggunaan dana, fotocopy rekening desa, surat keputusan kepala desa tentang tim pelaksana".

Bendahara desa juga menyampaikan:

"kalau ada salah satu lampiran yang tidak dimasukkan, maka dananya tidak bisa dicairkan, jadi harus benar-benar lengkap. Dana desa tahap selanjutnya juga bisa dicairkan kalau laporan tahap 1 sudah selesai dan sudah dilaporkan".

Setelah dana sudah cair maka program-program yang sudah disusun akan dilaksanakan. Kegiatan yang didanai oleh dana desa ini dilaksanakan oleh TPK (Tim Pelaksana Kegiatan) yang dibentuk oleh kepala desa. Hal ini diterangkan oleh sekretaris desa:

"Untuk pelaksanaan kegiatan, ada Tim Pelaksana Kegiatan yang ditetapkan oleh Kepala Desa untuk bertanggung jawab atas segala sesuatu yang berkaitan dengan pelaksanaan kegiatan. Tim Pelaksana Kegiatan wajib melaporkan kepada Kepala Desa".

Pada tahap ini, khususnya dalam pelaksanaan pembangunan yang terkait dengan infrastruktur, pendamping desa memiliki peran dalam mengukur jumlah bahan-bahan yang digunakan, misalnya suatu dusun akan membuat rabat beton, maka pendamping desa akan menghitung jumlah pasir yang digunakan, dan jumlah bahan-bahan yang lain. Hal ini dibenarkan oleh sekretaris desa:

"Pendamping akan desa turun langsung untuk melakukan pengukuran dan membantu dalam menghitung seberapa besar jumlah bahan dan biaya yang diperlukan dalam membuat suatu program yang telah disepakati di musrenbangdes".

Pada saat proses pembangunan, pendamping desa sesekali akan berkunjung untuk meninjau dan memantau proses pengerjaan program tersebut. Seperti yang diungkapkan pendamping desa:

"Kalau di desa ada namanya tim pelaksana, kalau masalah fisik koordinasinya ke tim pelaksana (menanyakan pengerjaannya sudah sampai mana), kemudian janjian untuk melakukan pemantauan langsung ke lapangan. Kalau dilapangan, pekerjaannya tidak sesuai maka akan dianjurkan untuk dilakukan revisi terhadap pengerjaan tersebut. Tidak tiap hari melakukan pemantauan".

Pada tahap akhir dari pelaksanaan ini, pendamping desa, aparat desa dan pihak inspektorat akan melakukan pemantauan dan pemeriksaan untuk melihat kesesuaian dari pembangunan yang telah dilakukan dengan yang direncanakan. Jika ada yang tidak sesuai, pendamping desa akan memberikan saran untuk melakukan perbaikan. Tahap pelaksanaan ini baru berfokus pada pembangunan infrastruktur desa karena pemberdayaan masyarakat desa baru akan difokuskan pada tahun anggaran 2020.

\section{Peran Pendamping Desa di Tahapan Penatausahaan}

Dalam proses penatausahaan di Desa Sepakung, aparat desa akan membuat pembukuan terkait dengan pengelolaan keuangan desa. Aparat desa akan menyiapkan buku pembantu kas umum, yang terdiri dari: buku pembantu bank, buku pembantu pajak dan buku pembantu panjar. Disamping itu, aparat desa juga akan mengoperasikan siskeudes untuk menginput data terkait pengelolaan keuangan desa secara terkomputerisasi. Hal tersebut sesuai dengan keterangan bendahara desa Sepakung:

"segala bentuk pemasukan dan pengeluaran tercatat dan harus melalui rekening desa. Setiap satu bulan sekali saya melaporkan keuangan kepada kepala desa".

Peran pendamping desa dalam tahap ini, yaitu memberikan saran-saran terkait administrasi yang sesuai dari pemerintah. Selain itu, pendamping desa akan memantau dan membantu apabila aparat desa 
kesulitan dalam mengoperasikan aplikasi siskeudes. Hal tersebut dibenarkan oleh sekretaris desa selaku admin dari siskeudes:

"Pendamping desa bertugas mendampingi aparat desa secara administrasi. Misalnya kalau kesulitan dalam mengoperasikan siskeudes, maka akan bertanya ke pendamping desa atau ke teman-teman admin siskeudes yang ada di desa lainnya".

Pendamping desa dalam hal ini tidak mengintervensi karena pendamping desa hanya membantu melakukan pendampingan, atau memberikan saran-saran atau menjawab pertanyaan aparat desa. Seperti yang disampaikan pendamping desa:

"Dalam proses penatausahaan, saya tidak mengintervensi desa terkait administrasinya. Saya hanya mendampingi saja. Ketika ada kesulitan saya akan berusaha bantu. Biasanya mendampingi di pengoperasian siskeudes karena kan setiap tahun siskeudes diperbaharui, jadi harus dipelajari lagi".

Pernyataan tersebut menunjukkan bahwa pendamping desa tetap melakukan perannya dalam melakukan pendampingan tetapi lebih ke arah teknis, khususnya dalam pengoperasian Siskeudes.

\section{Peran Pendamping Desa di Tahapan Pelaporan}

Pada tahap pelaporan, aparat desa akan membuat laporan realisasi pelaksanaan APB desa per semester. Laporan ini akan disampaikan oleh kepala desa kepada bupati/wali kota melalui camat. Selanjutnya, laporan realisasi pelaksanaan APB desa akan dilaporkan kepada menteri. Dalam proses pelaporan ini, kepala desa dituntut tepat waktu, karena jika terlambat maka Bupati/walikota berhak menunda pencairan dana berikutnya. Namun dalam praktiknya sejauh ini, aparat desa sudah tepat waktu dalam melakukan pelaporan. Sekretaris desa menyampaikan:

"Jika terjadi keterlambatan dalam menyampaikan laporan keuangan, desa yang akan rugi karena desa yang butuh dana tersebut, jadi jika laporan realisasi tahap sebelumnya terlambat dikumpulkan maka dana selanjutnya akan terlambat dicairkan".

Pendamping desa dalam tahapan pelaporan ini hanya sebagai pemberi saran, tidak membuatkan laporan. Pendamping desa juga akan melihat kesesuaian dari perencanaan dan realisasi. Kalau desa yang sudah mandiri biasanya pendamping desa hanya melakukan konfirmasi mengenai ketepatan waktu pembuatan laporan. Seperti yang disampaikan pendamping desa:

"kalau soal pelaporan itu biasanya saya hanya mendampingi dan melihat apakah perencanaan dan realisasi dari program ini sudah benar atau tidak. Tetapi lebih sering konfirmasi saja, biasanya saya bertanya ke desa "laporannya sudah sampai mana, pak? Apakah ada kesulitan?" kalau misalnya ada kesulitan saya berusaha untuk membantu".

Hal tersebut dibenarkan juga oleh kepala desa:

"kalau di pelaporan itu pendamping desa hanya sebagai pendamping saat aparat membuat laporan realisasi"

Sekretaris desa juga mengungkapkan hal yang sama:

"Pendamping desa mendampingi pada saat membuat laporan realisasi, pendamping desa yang melihat kesesuaian dari perencanaan dan realisasi"

Serta didukung oleh pendapat bendahara desa:

"Pendamping desa memberikan saran pada saat kesulitan dalam membuat laporan keuangan, misalnya mengenai format laporan realisasi" 
Pernyataan yang disampaikan oleh aparat desa tersebut menunjukkan bahwa pendamping desa melakukan perannya dalam hal mendampingi aparat desa dalam proses pelaporan pengelolaan keuangan desa untuk membangun infrastruktur dan pemberdayaan masyarakat.

Peran Pendamping Desa di Tahapan Pertanggungjawaban

Dalam proses pertanggungjawaban pengelolaan keuangan desa, aparat desa pada setiap akhir tahun anggaran akan menyampaikan laporan pertanggungjawaban APB desa kepada bupati/wali kota melalui camat. Laporan pertanggungjawaban disertai laporan realisasi APB desa dan catatan atas laporan keuangan, laporan realisasi kegiatan, dan daftar program desa. Laporan pertanggungjawaban tersebut wajib dilaporkan setiap akan melakukan pencairan. Dalam setahun, pencairan dilakukan sebanyak tiga kali yang di bagi dalam tiga tahap, tahap 1, tahap 2, tahap 3. Laporan pertanggungjawaban ini merupakan output dari siskeudes. Pada tahap ini, seperti yang diungkapkan pendamping desa:

"Pada saat melakukan pertanggungjawaban, saya hanya mendampingi saja. Tetapi kalau diminta oleh inspektorat untuk menjawab pertanyaan, saya jawab".

Pendamping desa dalam hal ini tidak mengintervensi jawaban. Hal ini juga dibenarkan oleh sekretaris desa:

"Pendamping desa di Desa Sepakung hanya mendampingi ketika melakukan pertanggungjawaban kepada pemerintah pusat dan menambahkan jawaban hanya ketika ada pertanyaan dari pemerintah kepada pendamping desa dan ketika dibutuhkan".

Pada tahapan penatausahaan, pendamping desa melakukan perannya untuk mendampingi desa dalam melakukan pertanggungjawaban kepada pemerintah pusat.

\section{Pembahasan}

Sesuai dengan Peraturan Menteri Desa Pembangunan Daerah Tertinggal Dan Transmigrasi Republik Indonesia No.3 Tahun 2015 Tentang Pendamping Desa khususnya pada pasal 12 Ayat (1) diungkapkan bahwa tugas pendamping desa adalah mendampingi desa dalam setiap tahap pengelolaan keuangan desa, yaitu perencanaan, pelaksanaan, dan pemantauan dalam pembangunan dan pemberdayaan masyarakat. Pada tahapan perencanaan, pendamping desa memiliki kontribusi penting dalam mengarahkan agar penyusunan rencana kegiatan sesuai dengan prioritas dan kebutuhan masyarakat. Dari hasil penelitian yang sudah didapatkan, tugas pendamping desa dalam proses perencanaan di Desa Sepakung sudah dilaksanakan sesuai Peraturan Menteri Desa Pembangunan Daerah Tertinggal Dan Transmigrasi Republik Indonesia No.3 Tahun 2015 Tentang Pendamping Desa. Hal tersebut terlihat dari penggunaan anggaran dana desa yang sudah tepat sasaran sesuai dengan prioritas kebutuhan masyarakat desa karena pendamping desa ikut serta dalam proses perencanaan dengan turun langsung ke masyarakat untuk menggali informasi dan mengikuti rapat dusun untuk mengarahkan masyarakat dusun dalam penyusunan setiap prioritas pembangunan dan pemberdayaan masyarakat yang dituangkan dalam RPJMDes. Sejauh ini belum ada kendala yang mengganggu tugas pendampingan yang dilakukan oleh pendamping desa.

Pada tahap pelaksanaan, peran dari pendamping desa dituntut agar dapat memfasilitasi kegiatan yang bersumber dari dana desa meliputi pembangunan yang lebih ditekankan kepada pengadaan infrastruktur atau sarana prasarana desa serta pemanfaatan sumber daya alam dan lingkungan secara berkelanjutan. Sedangkan pada aspek pemberdayaan masyarakat, pendamping desa lebih ditekankan untuk memfasilitasi pembinaan masyarakat terutama untuk penanggulangan kemiskinan dan peningkatan akses atas sumber daya ekonomi, sosial, budaya, kesehatan dan pendidikan di desa. Pada tahap pelaksanaan, program-program yang telah disepakati dalam musrenbangdes akan dikerjakan oleh tim pelaksana kegiatan. Contoh program yang dikerjakan pada pembangunan infrastruktur desa, seperti: pembuatan jembatan, rabat beton, pembangunan serta pengembangan objek wisata dan pemberdayaan masyarakat yang baru akan dilaksanaan, seperti: pelatihan-pelatihan kepada 
masyarakat. Tahap pelaksaan sejauh ini masih fokus pada pembangunan infrastruktur karena pemberdayaan masyarakat baru akan difokuskan di tahun anggaran 2020.

Dalam proses pelaksanaan, masih terdapat beberapa kendala, yaitu masih kurangnya tenaga teknik infrastruktur di lapangan, sehingga pada saat tim pelaksana mengalami kesulitan terkait masalah teknis akan berkoordinasi kepada pendamping desa. Pendamping desa terkadang kesulitan dalam membantu tim pelaksana kegiatan, khususnya pada saat di lapangan, misalnya dalam membuat gambar proyek, karena latar belakang pendidikan dari pendamping desa yang tidak sesuai dengan kebutuhan desa tersebut mengakibatkan pendamping desa kesulitan dalam membantu tim pelaksana kegiatan. Dalam hal ini yang menjadi kendala adalah bahwa pendamping desa dianggap mengetahui segala sesuatu, harus multi talent, padahal kemampuan dan latar belakang pendidikan dari pendamping desa berbedabeda. Sementara itu, pendamping desa belum terlalu memahami terkait dengan hal teknis khusus pada bagian jumlah bahan yang digunakan dalam proses pembangunan tersebut, sehingga mengharuskan untuk berkoordinasi dengan pendamping desa bagian teknis di kecamatan untuk membantu. Pada pemberdayaan masyarakat, sejauh ini belum ada kendala yang dialami karena pemberdayaan masyarakat baru mulai dilaksanakan pada tahun anggaran 2020 setelah sebelumnya fokus pada pembangunan infrastruktur desa.

Peran pendamping desa pada tahapan penatausahaan pengelolaan keuangan desa berkaitan dengan hal administrasi. Pendamping desa mendampingi aparat desa dalam proses pencatatan dan pengoperasian siskeudes. Namun dalam pendampingannya, pendamping desa terkadang kurang memahami terkait pengoperasian siskeudes karena kurang mendapat pelatihan dari pemerintah pusat, sehingga penerapan ke desa juga masih kurang optimal. Apalagi setiap tahun siskeudes selalu diperbaharui. Selain itu, pendamping desa hanya diberikan pembekalan hanya 1 kali, di awal pendamping desa dinyatakan diterima sebagai pendamping desa dan kegiatan pembekalan/pelatihan di padatkan selama 1 minggu. Jadi pendamping desa kurang menyerap informasi yang diberikan. Pada tahap pelaporan, pendamping desa akan mendampingi proses pembuatan laporan, namun tidak sampai membuatkan laporan. Pendamping desa berperan sebagai pemberi saran atau masukan terkait dengan laporan realisasi APBDes. Pendamping desa terkadang mendampingi desa dalam pembuatan laporan tersebut agar pada saat aparat desa kesulitan akan berkoordinasi ke pendamping desa untuk mendapat solusi. Kendala yang dialami oleh pendamping desa adalah kesulitan dalam membagi waktu antara mendampingi desa dan membuat laporan individu pendamping desa. Selain itu, Pendamping desa membawahi tiga desa sehingga intensitas pendampingannya kurang optimal. Selanjutnya, tahapan pertanggungjawaban yang merupakan tahap terakhir dalam proses pengelolaan keuangan desa. Pada tahap ini, pendamping desa hanya melakukan pendampingan jika diperlukan saja dan ikut menjawab pertanyaan dari inspektorat ketika diminta langsung oleh pemerintah. Artinya bahwa kewenangan dalam pembuatan laporan pertanggungjawaban diserahkan kepada pihak desa, pendamping desa merasa bahwa tugasnya sebatas pendampingan, jika desa sudah dianggap mandiri maka kebutuhan untuk didampingi akan kecil.

Dalam semua tahapan pengelolaan keuangan desa, pendamping desa akan melakukan pemantauan dalam pembangunan dan pemberdayaan masyarakat pada tahap perencanaan hingga tahap pertanggungjawaban pengelolaan keuangan desa. Pendamping desa merupakan pihak independen atau struktur eksternal desa yang hendaknya dapat memantau jalannya pengelolaan dana desa dengan baik agar program kegiatan yang dilaksanakan dapat sejalan dengan harapan pemerintah. Sementara untuk proses pemantauan yang dilakukan oleh pendamping desa di Desa Sepakung, Kecamatan Banyubiru, dilakukan di setiap tahapan pengelolaan keuangan desa untuk memantau jalannya pengelolaan keuangan desa khususnya dana desa dengan baik agar program kegiatan yang dilaksanakan dapat sejalan dengan keputusan musyawarah desa dan harapan pemerintah. Sesuai dengan hasil penelitian, pendamping desa belum melakukan pemantauan secara optimal. Ada beberapa kendala yang dialami oleh pendamping desa dalam pelaksanaan perannya, diantaranya pendamping desa yang ada di Desa Sepakung juga membawahi tiga desa sekaligus, sehingga proses pemantauan di lapangan tidak maksimal. Dari sisi desanya, untuk hal yang sama mengakibatkan kekurangan waktu ketika akan bertanya kepada pendamping desa dan pada akhirnya akan mengakibatkan peran pendamping desa menjadi tidak penting karena desa bisa langsung bertanya ke pihak lain tanpa harus ada pendamping desa. Kendala lain juga berkaitan dengan domisili atau tempat tinggal pendamping desa yang berada 
cukup jauh dari lokasi pendampingan sehingga terkendala waktu pada saat ada keperluan terhadap pendamping desa dan desa dampingan serta minimnya honor yang diterima oleh pendamping desa sehingga dinilai kurang sesuai dengan pekerjaan yang dilakukan. Selain itu, Pendamping desa merasakan kurangnya pelatihan yang dilakukan oleh pemerintah, akibatnya pendamping desa yang baru saja bergabung merasa kesulitan.

Hasil akhir dari proses pendampingan yang dilakukan oleh pendamping desa dalam tahap pengelolaan keuangan desa adalah pembuatan pelaporan individu pendamping desa. Laporan pendamping desa ini terbagi dalam 4 bab. Bab 1 tentang profil desa, bab 2 tupoksi dan bentuk dalam narasi yang berisi semua kegiatan yang dilakukan di setiap desa, bab 3 permasalahan, bab 4 rekomendasi dan juga lampiranlampiran lainnya seperti: lampiran daftar kegiatan, hasil kegiatan dan tindak lanjut, dan rencana kegiatan di bulan berikutnya serta daftar hadir kegiatan di desa dalam bentuk tulisan tangan. Laporan individu pendamping desa tersebut sudah memuat ketiga desa. Namun dalam pelaksanaannya, pendamping desa tidak setiap hari bisa berkunjung ke desa. Hal tersebut diakibatkan karena pendamping desa membawahi tiga desa sekaligus sehingga pendamping desa harus membagi waktu agar dapat mengunjungi desa-desa tersebut. Kendala lain yang dialami pendamping desa adalah minimnya honor pendamping desa yang juga menjadi pertimbangan ketika hendak melakukan tugasnya.

\section{SIMPULAN}

Secara umum peran Pendamping Desa yang ada di Desa Sepakung sudah dilaksanakan sesuai dengan Peraturan Menteri Desa, Pembangunan Daerah Tertinggal Dan Transmigrasi Republik Indonesia No.3 Tahun 2015 Tentang Pendamping Desa, khususnya pada pasal 12 Ayat (1) namun kurang optimal khususnya terkait pelaksanaan pengelolaan keuangan desa. Hal tersebut diakibatkan karena adanya beberapa kendala teknis dan nonteknis. Kendala teknis yang dialami pendamping desa adalah kurangnya tenaga teknik infrastruktur di lapangan, latar belakang pendidikan yang tidak sesuai dengan tugas pendamping desa, kurangnya pemahaman pendamping desa tentang siskeudes, kurangnya pelatihan yang diberikan kepada pendamping desa, dan pendamping desa membawahi tiga desa sekaligus. Sementara untuk kendala non teknisnya adalah jarak tempat tinggal pendamping desa dengan desa binaannya cukup jauh serta minimnya honor yang di terima pendamping desa, sehingga dirasa tidak seimbang dengan pekerjaannya yang dilakukan.

Penelitian yang dilakukan saat ini masih memiliki banyak keterbatasan khususnya dalam pengambilan data. Pada saat pengambilan data, ada beberapa narasumber yang sulit ditemui dan menentukan jadwal wawancara karena waktu yang terbatas. Dalam penelitian ini juga observasi tidak dilakukan karena keterbatasan waktu dan proses pengelolaan keuangan desa yang sudah sementara berjalan, jadi prosesnya tidak diikuti dari awal. Selain itu, ada beberapa narasumber yang kurang memahami peran Pendamping Desa sesuai undang-undang sehingga peneliti mengalami kesulitan ketika bermaksud melakukan penggalian informasi dengan lebih mendalam ketika melakukan wawancara.

Berdasarkan dari hasil penelitian yang telah dilakukan di Desa Sepakung, Kecamatan Banyubiru, peneliti memberikan saran sebagai bahan pertimbangan. Saran untuk penelitian berikutnya agar bisa melakukan penelitian terhadap peran pendamping desa di tingkat kecamatan dan perlu dilihat keterkaitan antara peran pendamping desa yang ada di kecamatan dan peran pendamping desa yang ada di desa. Penelitian berikutnya juga bisa menambahkan narasumber dari pihak masyarakat terkait dengan peran pendamping desa dalam memberdayakan masyarakat desa. Selain itu, penelitian berikutnya juga dapat membandingkan kinerja pendamping desa ketika di desa terpencil dan desa yang dekat dengan kota.

\section{REFERENSI}

Berdesa.com. (2018). Apa saja yang harus dilakukan Pendamping Desa. 10 Januari. http://www.berdesa.com/apa-saja-harus-dilakukan-pendamping-desa/ 
Bpkp.go.id. (2019). Peran BPKP dalam Pengawasan Dana Desa. 28 Agustus. http://www.bpkp.go.id/ntt/berita/read/22505/0/Peran-BPKP-dalam-Pengawasan-DanaDesa.bpkp

Kemendesa.go.id. (2015). Rencana Strategis Direktorat Jenderal Pembangunan Kawasan Perdesaan.

Kementerian Keuangan Republik Indonesia. (2019). Ini hasil dana desa sejak 2015.7 Januari. https://www.kemenkeu.go.id/publikasi/berita/ini-hasil-dana-desa-sejak-2015/

Kompas.com. (2015). Belum Ideal, Jumlah Pendamping Desa. 19 September. https://money.kompas.com/read/2015/09/19/183613226/Belum.Ideal.Jumlah.Pendamping.Des

a

Kompas.com. (2018). ICW: Ada 181 Kasus Korupsi Dana Desa, Rugikan Negara Rp 40,6 Miliar. 21 November. $\quad$ https://nasional.kompas.com/read/2018/11/21/19000481/icw-ada-181-kasuskorupsi-dana-desa-rugikan-negara-rp-406-miliar?page=all

Kontan.co.id. (2017). Kejaksaan Agung temukan enam masalah Dana Desa. 11 September. https://nasional.kontan.co.id/news/kejaksaan-agung-temukan-enam-masalah-dana-desa

Lestari, M. (2019). Punya 1.507 Desa, Apa Kendala Program Dana Desa di Ujung Sulawesi? 28 Agustus. https://finance.detik.com/berita-ekonomi-bisnis/d-4684212/punya-1507-desa-apa-kendalaprogram-dana-desa-di-ujung-sulawesi

Manafe, D. (2015). Belum Melek Akuntansi, Aparatur Bakal Kesulitan Kelola Dana Desa. 29 Januari. https://www.beritasatu.com/nasional/244773/belum-melek-akuntansi-aparatur-bakal-kesulitankelola-dana-desa

Peraturan Menteri Desa Pembangunan Daerah Tertinggal dan Transmigrasi No.3 Tahun 2015 tentang Pendamping Desa, 1 (2015).

Sepakung. (n.d.). Desa Sepakung. https://sepakung.id/struktur-organisasi/

Seputro, H. Y., Wahyuningsih, S. D., \& Sunrowiyati, S. (2017). Potensi Fraud dan Strategi Anti Fraud Pengelolaan Keuangan Desa. Penerapan Teori \& Terapan Akuntansi (PETA), 2, 79-93.

Simorangkir, E. (2017). Pemerintah Kucurkan Dana Desa Sejak 2015,Apa Saja Hasilnya? 19 Agustus. https://finance.detik.com/berita-ekonomi-bisnis/d-3606172/pemerintah-kucurkan-dana-desasejak-2015-apa-saja-hasilnya

Tribunnews.com. (2015). Pendamping Desa Digaji Rp 14 Juta Sebulan. 4 Agustus. https://www.tribunnews.com/regional/2015/08/04/pendamping-desa-digaji-rp-14-juta-sebulan

Undang-Undang Republik Indonesia Nomor 6 Tahun 2014 Tentang Desa, (2014). 